EGU2020-10943

https://doi.org/10.5194/egusphere-egu2020-10943

EGU General Assembly 2020

(c) Author(s) 2020. This work is distributed under

the Creative Commons Attribution 4.0 License.

\title{
Havelange deep borehole (Belgium): a study case for the evaluation of metasedimentary formations as potential geothermal reservoir - H2020 MEET project
}

\author{
Yves Vanbrabant ${ }^{1}$, Vinciane Stenmans ${ }^{2}$, Christian Burlet ${ }^{1}$, Estelle Petitclerc ${ }^{1}$, Bruno Meyvis ${ }^{1}$, \\ Giorgia Stasi ${ }^{1}$, Rhadityo Arbarim ${ }^{3}$, Kristian Bär ${ }^{3}$, and Thomas Goovaerts ${ }^{1}$ \\ ${ }^{1}$ RBINS-Geological Survey of Belgium, Brussels, Belgium (yvanbrabant@naturalsciences.be) \\ ${ }^{2}$ VS.GEOFORMA, Chaumont-Gistoux, Belgium \\ ${ }^{3}$ Group of Geothermal Science and Technology, Technische Universität Darmstadt, Germany
}

The outcrop areas of metamorphic rocks in continental setting cover significant regions and their extension zones are even more significant if we also consider the shallow and medium subsurface areas under the sedimentary cover. However, the metamorphic rocks are usually disregarded as potential geothermal reservoirs since they are considered as tight rocks with no or very limited porosity and permeability. Even if this statement is correct, the metamorphic units are frequently associated with a long and complex tectonic evolution and in particular with pre-, syn- and postmetamorphism fractures, which represent potential target zones for the development of geothermal reservoirs. Another limitation to assess the geothermal potentiality of the metamorphic units is the very limited number of deep exploration wells, especially in comparison to other well-investigated reservoirs, such as those located in sedimentary formations.

The anchizone and epizone metasedimentary rocks in Southern Belgium (Wallonia) cover more than $30 \%$ of the territory and probably more than $40 \%$ if we also consider the metamorphic rocks under the non-metamorphic formations. These statistics are based on the depth interval between $0 \mathrm{~km}$ (outcrop) and $6 \mathrm{~km}$, which are reasonable depths for the development of geothermal projects. The encountered lithologies consist of a few km-thick quartzite and slate formations of Lower Palaeozoic and Lower Devonian ages. These formations are associated with different events with the most significant ones regarding this study being the fracturing events related to the formation of the Rhenohercynian basin during the Devonian and the Dinantian times followed by the Variscan orogeny during Upper Carboniferous.

The Havelange borehole was drilled by the Geological Survey of Belgium between 1980-1985 as a gas exploration reaching a maximum depth of $5648 \mathrm{~m}$ (MD). The aim of this borehole was to investigate the presence/absence of a Carboniferous gas reservoir located under the main décollement level of the Ardenne Allochthon. Even if the borehole never reached any Carboniferous rocks, it allowed a better characterization of the transition between shallow Lower Famennian shale units and Lower Devonian meta-sedimentary formations, along with Middle Devonian rocks at intermediate depth. The study conducted in the framework of the H2020 MEET 
project (www.meet-h2020.com) for the Havelange study-site includes the re-investigation of cores, cuttings and log data acquired during the drilling. The laboratory study entails the mineralogical characterisation of the host rocks and fracture zones as well as the petrophysical and rock mechanical characterisation and this borehole material is completed with outcrop analyses and comparable measurements in analogue zones. The lab and field results are cross-matched with the drilling archives and in particular the drilling report indicating the depths of mud losses, representing intervals of great interest for the potential reconversion of this borehole into a geothermal well. 